\title{
Factors Influencing the Acceptance of Online Shopping in Pakistan
}

\author{
Samra Chaudary, , Sehrish Nisar, ${ }^{* *}$ Muhammad Abdul \\ $\operatorname{Rehman}^{* * *}$
}

\begin{abstract}
The rapid growth of the Internet and its extended reach has helped developing countries adopt e-commerce, thus enabling consumers to make transactions worldwide. This study identifies the factors related to online shopping and examines consumer motivation and acceptance in this context. We employ exploratory factor analysis, structural equation modeling, and cluster analysis and find that Pakistani consumers behave very differently from consumers in Western countries or countries that have adopted online shopping on a wide scale. While factors such as convenience and trust are seen to affect consumer behavior, other variables such as perceived price and information availability are less importance. The study also examines the reasons for this deviation from typical consumer behavior.
\end{abstract}

Keywords: online shopping, acceptance, risk.

JEL classification: M30, M31, M39.

\section{Introduction}

The Internet serves not only as a marketing platform for many companies, but also as a source of information for consumers making purchase decisions. The rapid growth of e-commerce has prompted researchers to examine which factors motivate consumers to accept online shopping (Clemes, Gan, \& Zhang, 2014). Ghaznavi (2013) notes that ecommerce has existed in Pakistan for some time and is still gaining traction with significant growth expected in the future. Chishti (2013) argues that social media have driven the rise in online shopping. There are over 100 online shopping websites operating in Pakistan and the bulk of this growth has occurred in the last two to three years. If it continues, e-commerce is likely to flourish in the country.

\footnotetext{
* Teaching fellow, Lahore School of Economics.

** Teaching fellow, Lahore School of Economics.

*** Research assistant, Lahore School of Economics.
} 
This study examines the factors underlying the acceptance of online shopping in Pakistan, drawing on the literature to identify these factors. Additionally, it incorporates detailed risk components, relative price, and the mediating factor of ease of use. Although other studies have looked at the risks associated with online shopping, we present a more detailed study of individual risk components, adding other variables to the framework. This allows us greater depth in examining why consumers opt for e-commerce.

While the literature has already identified the most common factors affecting consumer behavior in e-commerce, an important question to ask is whether all these factors necessarily apply to Pakistani consumers. This is important considering that e-commerce is still at an early stage and has yet to be widely accepted across the country. This study could prove useful in identifying not only consumer perceptions, but also in helping firms that are interested in adopting e-commerce to develop effective online retail strategies. In so doing, we combine the most relevant factors with any possible concerns a consumer might face when deciding to shop online. This helps provide a complete insight into how consumers behave. Given the dearth of research carried out in this area with reference to Pakistani consumers, the study's results could help large firms implement ecommerce more effectively.

Section 2 reviews the literature, Section 3 describes the methodology used, and Section 4 outlines the results of different techniques. Section 5 discusses the results obtained; Section 6 presents some managerial implications, limitations, and directions for future research.

\section{Literature Review}

This section discusses the literature based on each of the factors underlying the acceptance of online shopping.

\subsection{Convenience}

Convenience is defined as the time and effort saved when shopping and is a key motive for shopping online (Clemes et al., 2014); the intention to shop online increases in tandem with this factor (Swilley \& Goldsmith, 2013). Consumers do not have to leave home and are not bound by a time constraint as online shopping provides round-the-clock service, leaving consumers free to shop at their convenience (To, Liao, \& Lin, 2007). Our first hypothesis (H1) is that convenience has a positive relationship with the acceptance of online shopping. 


\subsection{Variety}

Online stores often provide a wider selection of goods than conventional stores. There is no physical limit on the stock an online store can display on its website, nor does it need to create attractive window displays. Variety is thus an important reason motivating consumers to shop online (To et al., 2007; Clemes et al., 2014). Consumers who shop online regularly may find they are better able to evaluate the product variety available (Sin \& Tse, 2002). Our second hypothesis (H2) is that variety has a positive relationship with the acceptance of online shopping.

\subsection{Customization}

Customization refers to the ways in which a particular website is tailored to its customers. The Internet provides one of the most suitable ways to personalize shopping such that customers can easily select their product specifications and packaging as required (To et al., 2007). Our third hypothesis $(\mathrm{H} 3)$ is that customization has a positive relationship with the acceptance of online shopping.

\subsection{Website Factors}

Clemes et al. (2014) describe websites as storehouses of information that help customers search for information. Website factors refer to the design characteristics that facilitate online purchase, i.e., content and design. Content includes the particulars of the merchandise available on the website, while design refers to the way the information is displayed (Huizingh, 2000). The design of a website is important because it is a key motivator for consumers who choose to use a particular shopping website; poorly designed websites discourage online transactions. Wolfinbarger and Gilly (2001) note that content and design are fundamental considerations for sellers structuring their websites.

\subsection{Ease of Use}

Ease of use, the mediator variable in this study, is defined as the extent to which a person perceives that working with a certain program is likely to be effortless (Davis, 1989). Applications that are perceived as being easier to use than others have a greater probability of being more widely accepted. Linking this to the concept of online shopping, Pérez-Hernández and Sánchez-Mangas (2011) identify ease of use as one of the factors that affect online shopping. Sites that enable customers to choose a product online easily are likely to retain their attention longer and lead to a positive 
purchase decision. Our fourth hypothesis (H4) is that website factors have a positive relationship with the acceptance of online shopping in the presence of the mediating variable, ease of use.

\subsection{Trust}

Kim, Yu, and Gupta (2012) define trust as the perception that a particular vendor is trustworthy. In this context, trust is the degree to which one expects that a website's up-to-date technology is likely to be dependable and credible (McKnight \& Chervany, 2002). Gefen and Straub (2003) point out that the perceived safety of making online transactions is a vital reason that some purchasers use the Internet but do not engage in any transactions. Ha and Stoel (2009) maintain that trust, while crucial in business relationships, is even more important in online transactions. When making online purchase decisions, consumers are exposed to greater risk and uncertainty, and this is countered by their trust in a particular website.

Freathy and Calderwood (2013) highlight the role of trust in the process of choosing a specific online retailer. Kim, Yu et al. (2012) argue that, if a particular vendor is perceived to be trustworthy, this directly reduces the risk associated with online shopping. Chang, Cheung, and Lai (2005) carry out an empirical study that suggests there is a significant and positive relationship between trust and online shopping intentions. Our fifth hypothesis (H5) is that trust has a positive relationship with the acceptance of online shopping.

\subsection{Information Availability}

To et al. (2007) observe that information availability comprises any information regarding merchandise, shops, and sales campaigns, etc. The information provided on a particular website helps consumers make better and more efficient decisions. Moreover, the Internet itself provides numerous explanatory resources and search tools that can help customers make efficient shopping decisions. Research and information search intent denotes the level at which shoppers utilize online shopping carts as a way of accumulating information on any merchandise they are considering for purchase (Close \& Kukar-Kinney, 2010). Our sixth hypothesis (H6) is that information availability has a positive relationship with the acceptance of online shopping. 


\subsection{Perceived Price}

Chiang and Dholakia (2003) point out that customers' choice of shopping channels is affected by the perceived prices associated with a particular site. Online customers compare prices across the same product or service offered by different websites in order to make the most effective economic decision (Clemes et al., 2014). Since they cannot always remember the objective price of an item, customers tend to encode purchase prices in a way that is meaningful to them.

While there is a vast range of websites from which customers can choose and acquire price information, they are likely to make their decision on the basis of perceived price. Perceived price affects consumer purchase behavior by affecting the total utility of the product offered (Kim, Yu et al., 2012). Kim and Gupta (2009) suggest that purchasers are likely to take into account the referral rates provided by different merchants. Our seventh hypothesis (H7) is that perceived price has a positive relationship with the acceptance of online shopping.

\subsection{Perceived Risk}

Perceived risk is the anticipated negative consequence of making a particular purchase (Dunn, Murphy, \& Skelly, 1986). E-commerce entails a greater degree of risk than traditional in-store shopping. An increase in overall perceived risk has a significant negative impact on attitudes toward online shopping. On the other hand, consumers are more likely to shop online when online stores provide sound security and privacy features (Clemes et al., 2014). Hong and Cha (2013) point out that shoppers perceive risk where earlier purchases have failed to meet their objectives. The uncertainty perceived by the customer in such a shopping decision determines the nature of the risk. Our eighth hypothesis (H8) is that perceived risk has a negative relationship with the acceptance of online shopping.

\subsubsection{Performance Risk}

Hong and Cha (2013) note that the risk associated with a product's performance is significant in the context of online shopping. Given that the product is not tangible, the customer must evaluate it based on the limited information available. There is an inherent risk in this because the consumer cannot examine the product physically before buying it (Bhatnagar, Misra, \& Rao, 2000). This may discourage some consumers 
from online shopping. On the other hand, some websites provide forums that enable consumers to interact with each other and record their experience of the product or service in question (Hong \& Cha, 2013). Purchasers reduce the product's performance risk by buying well-known brands (Aghekyan-Simonian, Forsythe, Kwon, \& Chattaraman, 2012).

\subsubsection{Online Payment Risk}

Hong and Cha (2013) identify online payment risk as a key consideration when evaluating the overall risk involved in online purchase. They point out that a number of surveys support this argument. Consumers may feel insecure about using online payment methods if they think there is a chance their confidential information and debit/credit card details might be recorded or exploited by hackers or Internet marketers without authorization.

\subsubsection{Delivery Risk}

Delivery risk is the risk that the purchased merchandise might be misplaced or shipped incorrectly as a result of inadequate online business expertise on the shipper's part (Hong \& Cha, 2013). Consumers who feel they will be spending money on something that might not reach them may be reluctant to make purchases online.

\subsubsection{Privacy Risk}

Customers have to provide a certain amount of private information when accessing shopping websites. This can raise concerns that such information might be misused, creating consumer uncertainty and increasing the overall perceived risk. Additionally, privacy concerns strongly influence customers' perception of the vendor (Lian \& Lin, 2008).

\subsection{Acceptance of Online Shopping}

Online shopping as defined by Monsuwé, Dellaert, and de Ruyter (2004) is the application of online shopping websites by customers up until the transactional phase of buying and logistics. Liu and Forsythe (2011) argue that a key shortcoming of studies that focus on explaining acceptance behavior is that they concentrate on the initial use of a particular system. Awareness of the selection process in Internet shopping and of the attitudes of online customers is vital for firms to remain competitive in an online marketplace (Clemes et al., 2014). 


\section{Theoretical Framework}

This section presents a theoretical framework for the study (see Figure 1) and is supplemented by the context below.

- Respondents. Respondents were selected on the basis of convenience sampling. This narrowed the scope and included respondents still at university or college and therefore not currently earning. Most respondents were from a high-income group corresponding to socioeconomic classes A and B-this may have played a factor in how they perceived online shopping and its associated risks. Most respondents were single, which may also have determined whether their needs were fulfilled through online shopping and how risky they considered e-commerce to be.

- Location. The data collected is mainly from Punjab. This raises the question as to whether the study would differ if carried out in other parts of the country, such as in Karachi, Pakistan's largest city. 


\section{Figure 1: Theoretical framework}

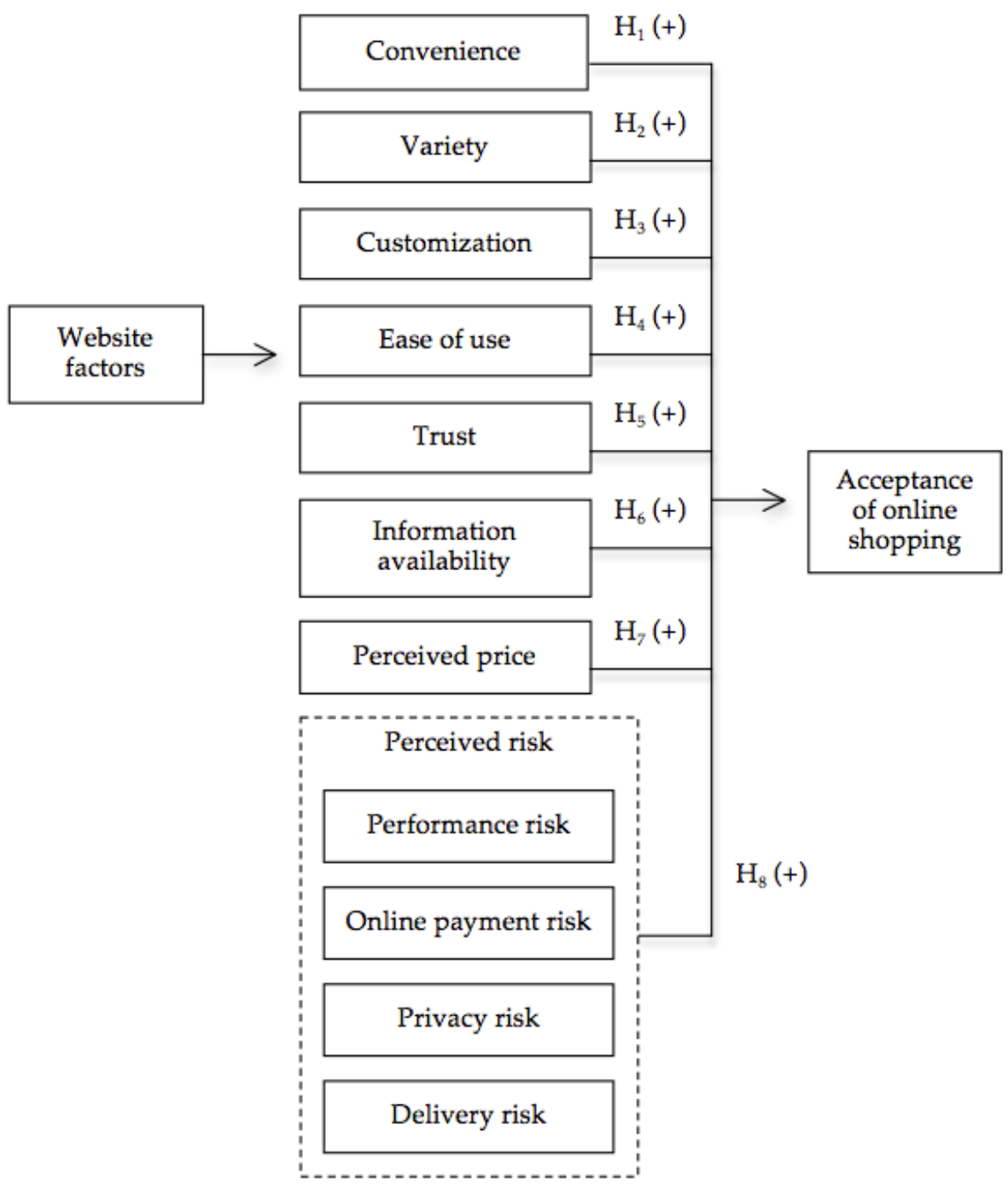

- Banking system. Certain features of Pakistan's banking system can create barriers to shopping online, e.g., many banks do not offer an online shopping facility on their debit cards.

- Economy. The recent growth of online shopping has had an inflationary impact and pushed up the prices of certain products. Currency devaluation has had a similar effect. Additionally, the customs system in Pakistan is poorly administered. These factors have discouraged consumers from using e-commerce and placing orders on international websites. 
- E-commerce in Pakistan. Domestic e-commerce operates differently from international e-commerce. In Pakistan, the most commonly used mode of payment is cash on delivery; consumers tend to avoid using credit cards. Emerging e-companies such as Homeshopping and Shophive offer cash-on-delivery services in multiple cities. This affects consumers' attitude to the risks associated with online shopping on Pakistani websites. Furthermore, such websites offer little flexibility.

- Time. The study was conducted at a time when the concept of online shopping had just begun to gain wider acceptance. Subsequent improvements in the operation of e-commerce imply that the results may be subject to change. As e-commerce continues to grow and it receives more support from financial institutions, the results are likely to become more positive.

\section{Data and Methodology}

This section describes the sample, measures, and methodology employed.

\subsection{Sample Size}

In determining an appropriate sample size, Shah and Goldstein (2006) show that small samples are associated with bias and low reliability. It is difficult to determine an adequate sample size for a structural equation model (SEM), which depends on a number of features. Keeping this in mind, the present study needs a minimum sample size of 200. Swilley and Goldsmith (2013) use 225 valid responses while Kim, Kim, and Park (2010) use 264. Accordingly, our sample comprises 221 respondents.

\subsection{Measures and Methodology}

The items in the study's structured questionnaire are measured on the Likert scale and are drawn from different studies (Table 1). The data has been analyzed for sample size characteristics and common method bias (using Harman's single-factor test). Following Lian and Lin (2008), we use varimax rotation for the exploratory factor analysis (EFA). The appropriateness of the sample size is checked using the Kaiser-MayerOlkin (KMO) test. The benchmark for sample adequacy is 0.7 or above. The total variance explained is compared with the benchmark of 60 percent. The rotated component matrix provides variables and items that are derived by the software along with their loadings, which are then compared with a benchmark of 0.45 . Finally, Cronbach's alpha is computed to check internal consistency. 
The results derived from the EFA are then further analyzed using a SEM, a measurement model employing confirmatory factor analysis (CFA), and a structural model employing path analysis. We use AMOS 21.0 to determine the validity and reliability of the constructs and to test the hypotheses. A number of measures are evaluated, including the average variance extracted (AVE), discriminant validity, and construct reliability. The benchmarks for AVE and construct reliability are 0.4 and 0.7 , respectively.

It is important to analyze the fit indices of the measurement and structural models. The standalone indices reported include the CMIN/df (adjusted for degrees of freedom), goodness of fit (GFI), adjusted goodnessof-fit (AGFI), and the root mean square error of approximation (RMSEA). The incremental indices include the normed fit index (NFI), comparative fit index (CFI), Tucker-Lewis Index (TLI), and incremental fit index (IFI).

We follow Iacobucci's (2008) approach to testing for mediation rather than the popular Baron and Kenny approach, given that the latter is associated with a number of problems (see MacKinnon, Fairchild, \& Fritz, 2007; Krause et al., 2010; Zhao, Lynch, \& Chen, 2010). Iacobucci suggests that the SEM rules the Baron and Kenny approach. Testing for mediation requires an indirect significant effect, but should start with observing whether the direct effect is significant. A more rigorous test is the bootstrap test (at a 95 percent confidence interval), which is stronger than the Sobel test at a 95 percent confidence interval (Zhao et al., 2010).

Finally, a cluster analysis is carried out to evaluate uniformity among the respondents and assess how many fall into the same category. The respondents are divided into different segments based on their attributes (in turn, determined by their responses). This is important because respondents vary in terms of preference characteristics.

\section{Results}

This section discusses the results obtained from the study.

\subsection{Sample Characteristics and Common Method Bias}

The results indicate that 69.7 percent of the respondents fall in the age bracket of 18-25, while 129 respondents have an undergraduate degree. The sample is fairly equally distributed between women and men.

The benchmark for skewness and kurtosis is $+/-2$. The data indicate that the descriptive statistics are not skewed and only one variable-marital 
status-surpasses the benchmark with a value of 2.339. In the case of kurtosis, the values of age and marital status exceed the benchmark, while that of gender is exactly equal to 2 . While any deviations from normality may initially appear to be large, they are in fact immaterial. To ensure that there is no common method bias, we apply Harman's one-factor test. We find that no one construct explains more than 45 percent of the variance and the maximum variance achieved by a single construct is 23.7 percent.

\subsection{Exploratory Factor Analysis}

The initial data encompassed 13 latent variables measured using a total of 61 items. Table 1 gives the position of each item with its respective variable and loadings.

Table 1: EFA and alpha values

\begin{tabular}{lccl}
\hline $\begin{array}{l}\text { Variable and } \\
\text { component }\end{array}$ & $\begin{array}{c}\text { Standardized } \\
\text { loading }\end{array}$ & $\begin{array}{c}\text { Cronbach's } \\
\text { alpha }\end{array}$ & \multicolumn{1}{c}{ Studies } \\
\hline Trust & 0.844 & 0.899 & Hong \& Cha (2013) \\
T2 & 0.822 & & Kim et al. (2010) \\
T3 & 0.778 & & \\
T4 & 0.768 & & \\
T1 & 0.677 & & \\
T5 & 0.845 & 0.913 & Hong \& Cha (2013) \\
\hline Acceptance of online shopping & & Lian \& Lin (2008) \\
AO2 & 0.835 & & \\
AO3 & 0.797 & & Clemes et al. (2014) \\
AO1 & 0.769 & & To et al. (2007) \\
AO4 & & & \\
\hline Variety & 0.796 & 0.847 & \\
V5 & 0.783 & & \\
V4 & 0.729 & & Ha \& Stoel (2009) \\
V1 & 0.593 & & Smith, Milberg, \& Burke \\
V3 & 0.497 & & (1996) \\
V2 & & & \\
\hline Privacy risk & 0.836 & 0.828 & \\
PRR7 & 0.767 & & \\
PRR8 & 0.755 & & \\
PRR6 & & & \\
\hline
\end{tabular}




\begin{tabular}{|c|c|c|c|}
\hline $\begin{array}{l}\text { Variable and } \\
\text { component }\end{array}$ & $\begin{array}{c}\text { Standardized } \\
\text { loading }\end{array}$ & $\begin{array}{c}\text { Cronbach's } \\
\text { alpha }\end{array}$ & Studies \\
\hline PRR3 & 0.737 & & \\
\hline PRR5 & 0.520 & & \\
\hline \multicolumn{4}{|l|}{ Convenience } \\
\hline $\mathrm{C} 4$ & 0.768 & 0.861 & Swilley \& Goldsmith (2013) \\
\hline $\mathrm{C} 3$ & 0.681 & & Clemes et al. (2014) \\
\hline $\mathrm{C} 2$ & 0.619 & & To et al. (2007) \\
\hline $\mathrm{C} 1$ & 0.595 & & \\
\hline C6 & 0.567 & & \\
\hline \multicolumn{4}{|c|}{ Performance risk } \\
\hline PR2 & 0.809 & 0.812 & Hong \& Cha (2013) \\
\hline PR3 & 0.780 & & Liu \& Forsythe (2011) \\
\hline PR1 & 0.691 & & \\
\hline PR4 & 0.633 & & \\
\hline \multicolumn{4}{|l|}{ Ease of use } \\
\hline EU3 & 0.781 & 0.784 & Davis (1989) \\
\hline EU4 & 0.778 & & \\
\hline EU2 & 0.733 & & \\
\hline EU1 & 0.632 & & \\
\hline \multicolumn{4}{|l|}{ Delivery risk } \\
\hline DR1 & 0.812 & 0.851 & Hong \& Cha (2013) \\
\hline DR2 & 0.808 & & \\
\hline DR3 & 0.767 & & \\
\hline \multicolumn{4}{|c|}{ Online payment risk } \\
\hline OR1 & 0.839 & 0.866 & Hong \& Cha (2013) \\
\hline OR2 & 0.828 & & \\
\hline OR3 & 0.693 & & \\
\hline \multicolumn{4}{|c|}{ Website factors } \\
\hline WF4 & 0.793 & 0.832 & Clemes et al. (2014) \\
\hline WF5 & 0.781 & & Ha \& Stoel (2009) \\
\hline WF3 & 0.699 & & \\
\hline \multicolumn{4}{|c|}{ Customization } \\
\hline CS3 & 0.820 & 0.794 & To et al. (2007) \\
\hline CS2 & 0.752 & & \\
\hline CS4 & 0.737 & & \\
\hline \multicolumn{4}{|c|}{ Information availability } \\
\hline IA2 & 0.632 & 0.836 & To et al. (2007) \\
\hline
\end{tabular}




\begin{tabular}{lccc}
\hline $\begin{array}{l}\text { Variable and } \\
\text { component }\end{array}$ & $\begin{array}{c}\text { Standardized } \\
\text { loading }\end{array}$ & $\begin{array}{c}\text { Cronbach's } \\
\text { alpha }\end{array}$ & Studies \\
\hline IA3 & 0.623 & & \\
IA1 & 0.607 & & \\
\hline Perceived price & & 0.633 & Kim, Yu et al. (2012) \\
PP1 & 0.792 & & \\
PP2 & 0.768 & & \\
\hline
\end{tabular}

Source: Authors' calculations.

Given a factor loading threshold of 0.45 (Clemes et al., 2014), the final analysis is based on 49 items, all of which have a factor loading of above 0.45 . Table 1 also reports the computed Cronbach's alpha for each variable, where acceptable values should be above 0.6 (Lian \& Lin, 2008; Liu \& Forsythe, 2011; Clemes et al., 2014). The results indicate that most of the variables have a high alpha value, which confirms the study's reliability.

Black and Porter (1996) propose a threshold of 0.8 to assess the appropriateness of the sample, based on the KMO test. Our computed value of 0.861 indicates that the sample is adequate. The result obtained for Bartlett's test of sphericity is also significant.

\subsection{Measurement Model}

CFA entails associating the latent variables with their measured variables by restricting the former to load with their respective measured variables such that they are allowed to correlate. Table 2 evaluates the standardized loading of each item under the variables concerned. All the items meet the benchmark value of 0.45 . The AVE is greater than 0.4 , and thus also acceptable (Verhoef, Franses, \& Hoekstra, 2002; Wu, Chen, Chen, \& Chen, 2014). Subramanian et al. (2014) accept a reliability measure as low as 0.6171 . Accordingly, all the values we have computed are deemed acceptable. We also find that the squared covariances are less than the AVE, indicating that discriminant validity holds. 
Table 2: CFA loadings, reliability, and validity

\begin{tabular}{|c|c|c|c|c|c|}
\hline Variable & Item & $\begin{array}{c}\begin{array}{c}\text { Standardized } \\
\text { loading }\end{array} \\
\end{array}$ & AVE & CR & DV \\
\hline \multirow{5}{*}{ Trust } & T3 & 0.88 & 0.639 & 0.898 & 0.799 \\
\hline & $\mathrm{T} 2$ & 0.84 & & & \\
\hline & $\mathrm{T} 4$ & 0.81 & & & \\
\hline & $\mathrm{T} 1$ & 0.75 & & & \\
\hline & T5 & 0.71 & & & \\
\hline \multirow[t]{5}{*}{ Variety } & V5 & 0.90 & 0.587 & 0.875 & 0.766 \\
\hline & V4 & 0.85 & & & \\
\hline & V2 & 0.71 & & & \\
\hline & V3 & 0.70 & & & \\
\hline & V1 & 0.64 & & & \\
\hline \multirow[t]{5}{*}{ Convenience } & $\mathrm{C} 1$ & 0.79 & 0.540 & 0.854 & 0.735 \\
\hline & $\mathrm{C} 2$ & 0.78 & & & \\
\hline & $\mathrm{C} 3$ & 0.76 & & & \\
\hline & C4 & 0.67 & & & \\
\hline & C6 & 0.67 & & & \\
\hline \multirow[t]{2}{*}{ Perceived price } & PP1 & 0.78 & 0.484 & 0.648 & 0.696 \\
\hline & PP2 & 0.59 & & & \\
\hline \multirow[t]{3}{*}{ Customization } & CS3 & 0.87 & 0.585 & 0.807 & 0.765 \\
\hline & CS2 & 0.75 & & & \\
\hline & CS4 & 0.66 & & & \\
\hline \multirow[t]{4}{*}{ Ease of use } & EU2 & 0.74 & 0.477 & 0.784 & 0.690 \\
\hline & EU3 & 0.71 & & & \\
\hline & EU1 & 0.69 & & & \\
\hline & EU4 & 0.62 & & & \\
\hline \multirow[t]{3}{*}{ Website factors } & WF4 & 0.83 & 0.626 & 0.834 & 0.791 \\
\hline & WF5 & 0.78 & & & \\
\hline & WF3 & 0.76 & & & \\
\hline \multirow[t]{3}{*}{ Information availability } & IA1 & 0.85 & 0.635 & 0.839 & 0.797 \\
\hline & IA2 & 0.80 & & & \\
\hline & IA3 & 0.73 & & & \\
\hline \multirow[t]{4}{*}{ Perceived risk } & OR & 0.73 & 0.431 & 0.747 & 0.656 \\
\hline & DR & 0.72 & & & \\
\hline & PRR & 0.67 & & & \\
\hline & PR & 0.48 & & & \\
\hline \multirow{4}{*}{$\begin{array}{l}\text { Acceptance of online } \\
\text { shopping }\end{array}$} & $\mathrm{AO} 1$ & 0.92 & 0.747 & 0.922 & 0.865 \\
\hline & $\mathrm{AO} 2$ & 0.86 & & & \\
\hline & $\mathrm{AO} 2$ & 0.86 & & & \\
\hline & $\mathrm{AO} 4$ & 0.82 & & & \\
\hline
\end{tabular}

Source: Authors' calculations. 
Shah and Goldstein (2006) argue that assessing a model's fit takes on increased complication. The values in our model for these measures are given below. These values are deemed acceptable and the overall model is, therefore, judged to be satisfactory (see Zarei, Zainalipour, Mohammadi, \& Zare, 2013).

\begin{tabular}{lllc}
\hline Standalone indices & & & Incremental indices \\
\hline CMIN/df & $1.497^{*}$ & CFI & 0.911 \\
GFI & 0.789 & TLI & 0.902 \\
AGFI & 0.758 & NFI & 0.776 \\
RMSEA & 0.050 & IFI & 0.913 \\
\hline
\end{tabular}

Note: ${ }^{*}=$ insignificant $p$-value.

\subsection{Structural Model}

The structural model analyzes the relationships among the variables and the significance of these relationships (Table 3). At this point, we are able to reject or accept the study's hypotheses. The results suggest that convenience, variety, and trust have a significant positive relationship with the acceptance of online shopping. This is in line with hypotheses H1, $\mathrm{H} 2$, and $\mathrm{H} 5$, respectively. We therefore accept these three hypotheses. The hypotheses for the variables customization, information availability, perceived price, and perceived risk are, however, rejected.

Table 3: Structural model and hypothesis testing

\begin{tabular}{|c|c|c|c|c|c|}
\hline & Hypothesis and relationship & $\begin{array}{l}\text { Predicted } \\
\text { sign }\end{array}$ & $\begin{array}{c}\text { Estimate } \\
(\boldsymbol{\beta})\end{array}$ & $\begin{array}{c}\text { P- } \\
\text { value }\end{array}$ & Decision \\
\hline $\mathrm{H} 1$ & $\begin{array}{l}\text { Convenience } \rightarrow \text { acceptance of } \\
\text { online shopping }\end{array}$ & + & 0.750 & $* * *$ & Accept \\
\hline $\mathrm{H} 2$ & $\begin{array}{l}\text { Variety } \rightarrow \text { acceptance of } \\
\text { online shopping }\end{array}$ & + & 0.218 & $* * *$ & Accept \\
\hline H3 & $\begin{array}{l}\text { Customization } \rightarrow \text { acceptance } \\
\text { of online shopping }\end{array}$ & + & -0.082 & 0.251 & Reject \\
\hline \multirow[t]{2}{*}{$\mathrm{H} 4$} & Website factors $\rightarrow$ ease of use & + & -0.119 & 0.197 & \multirow{2}{*}{$\begin{array}{l}\text { No } \\
\text { mediation }\end{array}$} \\
\hline & $\begin{array}{l}\text { Ease of use } \rightarrow \text { acceptance of } \\
\text { online shopping }\end{array}$ & + & 0.015 & 0.832 & \\
\hline H5 & $\begin{array}{l}\text { Trust } \rightarrow \text { acceptance of online } \\
\text { shopping }\end{array}$ & + & 0.193 & 0.010 & Accept \\
\hline
\end{tabular}




\begin{tabular}{llcccc}
\hline Hypothesis and relationship & $\begin{array}{c}\text { Predicted } \\
\text { sign }\end{array}$ & $\begin{array}{c}\text { Estimate } \\
(\boldsymbol{\beta})\end{array}$ & $\begin{array}{c}\text { P- } \\
\text { value }\end{array}$ & Decision \\
\hline H6 & $\begin{array}{l}\text { Information availability } \rightarrow \\
\text { acceptance of online } \\
\text { shopping }\end{array}$ & + & 0.009 & 0.896 & Reject \\
H7 $\begin{array}{l}\text { Perceived price } \rightarrow \text { acceptance } \\
\text { of online shopping }\end{array}$ & + & -0.074 & 0.433 & Reject \\
H8 $\begin{array}{l}\text { Perceived risk } \rightarrow \text { acceptance } \\
\text { of online shopping }\end{array}$ & - & 0.055 & 0.607 & Reject \\
\hline
\end{tabular}

Note: ${ }^{* * *} \mathrm{p}<0.01$.

Source: Authors' calculations.

Table 3 shows that the relationships are not significant in these cases. Moreover, perceived risk has the opposite relationship with the acceptance of online shopping (relative to the predicted sign). The relationships between website factors and ease of use, and between ease of use and the acceptance of online shopping are also insignificant (see Section 5.5). The computed values of the model fit indices for the path analysis are given below.

\begin{tabular}{lllr}
\hline Standalone indices & & & Incremental indices \\
\hline CMIN/df & $1.976^{*}$ & CFI & 0.819 \\
GFI & 0.690 & TLI & 0.807 \\
AGFI & 0.657 & IFI & 0.821 \\
\hline
\end{tabular}

Note: ${ }^{*}=$ insignificant $\mathrm{p}$-value.

Apart from the GFI and AGFI, all the other indices are acceptable (see Zarei et al., 2013). The $\mathrm{R}^{2}$ value for the acceptance of online shopping is 0.47 , indicating that the variable has 47 percent explanatory power in the model. Ease of use, however, has weak explanatory power (1 percent).

\subsection{Mediation}

Clemes et al. (2014) find a direct relationship between website factors and online shopping in the Chinese business context. We introduce a mediator, however, to determine if the relationship is strengthened or weakened. The results in Table 4 indicate that ease of use does not function as a mediator in this relationship, which itself remains highly significant while the indirect relationship is insignificant. We therefore reject $\mathrm{H} 4$. 
Table 4: Mediating effect

\begin{tabular}{lcccl}
\hline $\begin{array}{l}\text { Relationship (ease of } \\
\text { use as a mediator) }\end{array}$ & $\begin{array}{c}\text { Direct, without } \\
\text { mediator }\end{array}$ & $\begin{array}{c}\text { Direct, with } \\
\text { mediator }\end{array}$ & $\begin{array}{c}\text { Indirect, with } \\
\text { mediator }\end{array}$ & Results \\
\hline $\begin{array}{l}\text { Website factors } \rightarrow \\
\text { acceptance of online }\end{array}$ & 0.001 & 0.001 & 0.183 & $\begin{array}{l}\text { No } \\
\text { mediation }\end{array}$ \\
shopping & & & & \\
\hline
\end{tabular}

Source: Authors' calculations.

\subsection{Cluster Analysis}

In order to segment the market into different groups or clusters, we carry out a hierarchal cluster analysis (see Yen, da Gama, \& Rajamohan, 2008). Four clusters are generated using K means. Cluster 1 comprises 23 respondents who associate online shopping with a high level of risk and thus do not find the prospect attractive. This cluster is titled "no acceptability." Cluster 2 is composed of 43 respondents who exhibit the most positive attitude toward online shopping, i.e., they consider online shopping to be convenient and trustworthy, while the risk is seen to be small and unimportant. The cluster is titled "maximum acceptability."

Cluster 3 combines the attributes of the first two clusters: respondents want to shop online but consider doing so highly risky. This cluster contains 65 respondents and is titled "fearful acceptability." Cluster 4, with 90 respondents, is neutral about every aspect of online shopping, whether positive or negative, and is titled "neutral acceptability."

\section{Discussion}

Convenience is the key motivator for consumers who choose to shop online (Clemes et al., 2014). Our research clearly shows that, in line with the earlier hypothesis, convenience has the highest positive relationship with the acceptance of online shopping. Swilley and Goldsmith (2013) note that convenience in this context implies an easier shopping experience, freedom of time, and less effort.

The second underlying motivation for online shopping is variety (Clemes et al., 2014). To et al. (2007) show that shops may be reluctant to stock products catering to niche markets, which leaves a portion of the market disappointed. However, a wider range of products eventually leads to better decision-making (Keeney, 1999). When consumers find they can make better purchase decisions through e-shopping, this creates greater 
motivation to purchase. Variety ultimately has a positive impact on the acceptance of shopping online, which the study's results support.

Gefen and Straub (2003) suggest that trust is another major concern when consumers decide whether to make a purchase over the Internet. In the absence of physical interaction with the seller, the risk to the buyer increases. Ha and Stoel (2009) support this argument, indicating that the importance of trust increases in online shopping. This also holds true for Pakistan. Our results imply that there is a significant positive relationship in this case, although the impact is not as large as for the variables convenience and variety.

Website factors play a key role in e-shopping (Clemes et al., 2014) and, traditionally, have had a direct relationship with the acceptance of online shopping. We find that the direct relationship is significant and that mediation plays no role. This is supported by the existing literature. Ease of use alone does not, therefore, affect the relationship.

Pakistan-based websites offer little, if any, flexibility, e.g., customers do not have the option to alter the available products. On the other hand, international shopping websites that might offer customization may not deliver to Pakistan. Consumers, therefore, adjust without the option to customize. As a result, we reject the hypothesis concerning customization.

The relationship with perceived price is negative and insignificant. This can be attributed to the fact that most of our respondents were from a higher income group for which price would not have been as important a factor. The negative relationship can be explained by increased prices due to inflation and currency fluctuations, such that customers no longer perceive e-commerce as being cheaper than conventional shopping.

Although information availability has a positive impact, its significance is too low for us to accept the hypothesis. Despite the high level of information available, consumers remain inclined to purchase from known shops. This may be due to the importance of interpersonal relations among Pakistani consumers, who rely on the convenience that traditional shop owners are willing to provide. This limits their reliance on the Internet to serving as a source of information rather than purchase.

Finally, perceived risk was measured using four latent variables: performance risk, online payment risk, delivery risk, and privacy risk. Given that most Pakistani companies offer cash on delivery, this directly 
reduces the four risk components. Moreover, financial institutions do not enable online shopping with debit cards, which also decreases the risk. Online firms such as i-Shopping have started to provide one-year warranties, which reduces performance risk. The overall risk factor is insignificant because there are enough channels provided to avoid these risks. If online shopping in Pakistan were the same as it is in Western countries, there would be more scope for studying the potential risks.

\section{Limitations, Future Research, and Managerial Implications}

In attempting to study the behavior of Pakistani consumers toward online shopping, there are still some issues to consider. First, the structure of online shopping in Pakistan is very different from that in the West, which implies that the variables we have used are not necessarily suitable in each case. Second, the data was collected through convenience sampling and was restricted to a specific geographical area-this may have affected the results. Third, the study is based on the perception of consumers toward online shopping with no distinction between users and nonusers. Fourth, the current state of the economy does not necessarily favor high consumer spending. This, accompanied by the devaluation of the Pakistani rupee, may have discouraged many consumers from shopping online.

If, in the future, e-commerce in Pakistan becomes more like ecommerce in the West, the results may change as risk components such as financial, social, and psychological risk come into play. New variables such as the type of product and moderators such as users and nonusers could also be applied. The risk components could be studied independently and not as second-order variables. Future changes in the economy that lead to higher spending and a more stable currency could also change the study's results. Finally, while we have restricted ourselves to a particular culture, the study could be extended to incorporate a multicultural comparison.

Online shopping is, nonetheless, becoming an important factor in achieving efficient sales growth. Managers need to include and invest in this factor in the development of their online business models. Catering to the concerns of e-consumers would enable firms to develop better business strategies. The study's findings are relevant not only to existing businesses, but also new businesses, which could use these to develop effective policies. Taking both the positive and negative aspects into account would help managers who are planning to adopt e-commerce. 


\section{References}

Aghekyan-Simonian, M., Forsythe, S., Kwon, W. S., \& Chattaraman, V. (2012). The role of product brand image and online store image on perceived risks and online purchase intentions for apparel. Journal of Retailing and Consumer Services, 19(3), 325-331.

Bhatnagar, A., Misra, S., \& Rao, H. R. (2000). On risk, convenience, and Internet shopping behavior. Communications of the ACM, 43(11), 98-105.

Black, S. A., \& Porter, L. J. (1996). Identification of the critical factors of TQM. Decision Sciences, 27(1), 1-21.

Chang, M. K., Cheung, W., \& Lai, V. S. (2005). Literature derived reference models for the adoption of online shopping. Information and Management, 42(4), 543-559.

Chiang, K.-P., \& Dholakia, R. R. (2003). Factors driving consumer intention to shop online: An empirical investigation. Journal of Consumer Psychology, 13(1-2), 177-183.

Chishti, S. M. (2013, November 1). Social media is driving online shopping in Pakistan. Pakistan Tribune. Retrieved 29 November 2013, from http://www.pakistantribune.com.pk/6255/socialmedia-is-driving-online-shopping-inpakistan.html\#sthash.ef5HxRvU.dpuf

Clemes, M. D., Gan, C., \& Zhang, J. (2014). An empirical analysis of online shopping adoption in Beijing, China. Journal of Retailing and Consumer Services, 21(3), 364-375.

Close, A. G., \& Kukar-Kinney, M. (2010). Beyond buying: Motivations behind consumers' online shopping cart use. Journal of Business Research, 63(9-10), 986-992.

Davis, F. D. (1989). Perceived usefulness, perceived ease of use, and user acceptance of information technology. MIS Quarterly, 13(3), 319-340.

Dunn, M. G., Murphy, P. E., \& Skelly, G. U. (1986). Research note: The influence of perceived risk on brand preference for supermarket products. Journal of Retailing, 62(2), 204-216. 
Freathy, P., \& Calderwood, E. (2013). The impact of Internet adoption upon the shopping behavior of island residents. Journal of Retailing and Consumer Services, 20(1), 111-119.

Gefen, D., \& Straub, D. W. (2003). Managing user trust in B2C e-services. e-Service Journal, 2(2), 7-24.

Ghaznavi, A. (2013, July 1). Online shopping, the new trend in Pakistan. Pakistan Today. Retrieved 29 November 2013, from http://www.pakistantoday.com.pk/2013/07/01/news/profit/o nilne-shopping-the-new-trend-in-pakistan/

Ha, S., \& Stoel, L. (2009). Consumer e-shopping acceptance: Antecedents in a technology acceptance model. Journal of Business Research, $62(5), 565-571$.

Hong, I. B., \& Cha, H. S. (2013). The mediating role of consumer trust in an online merchant in predicting purchase intention. International Journal of Information Management, 33(6), 927-939.

Huizingh, E. (2000). The content and design of websites: An empirical study. Information and Management, 37(3), 123-134.

Iacobucci, D. (Ed.). (2008). Mediation analysis. Thousand Oaks, CA: Sage.

Keeney, R. L. (1999). The value of Internet commerce to the customer. Management Science, 45(4), 533-542.

Kim, C., Galliers, R. D., Shin, N., Ryoo, J.-H., \& Kim, J. (2012). Factors influencing Internet shopping value and customer repurchase intention. Electronic Commerce Research and Applications, 11(4), 374387.

Kim, H.-W., \& Gupta, S. (2009). A comparison of purchase decision calculus between potential and repeat customers of an online store. Decision Support Systems, 47(4), 477-487.

Kim, H.-W., Xu, Y., \& Gupta, S. (2012). Which is more important in Internet shopping, perceived price or trust? Electronic Commerce Research and Applications, 11(3), 241-252. 
Kim, J. U., Kim, W. J., \& Park, S. C. (2010). Consumer perceptions on Web advertisements and motivation factors to purchase in the online shopping. Computers in Human Behavior, 26(5), 1208-1222.

Krause, M. R., Serlin, R. C., Ward, S. E., Rony, R. Y., Ezenwa, M. O., \& Naab, F. (2010). Testing mediation in nursing research: Beyond Baron and Kenny. Nursing Research, 59(4), 288-294.

Lian, J.-W., \& Lin, T.-M. (2008). Effects of consumer characteristics on their acceptance of online shopping: Comparisons among different product types. Computers in Human Behavior , 24(1), 48-65.

Liu, C., \& Forsythe, S. (2011). Examining drivers of online purchase intensity: Moderating role of adoption duration in sustaining post-adoption online shopping. Journal of Retailing and Consumer Services, 18(1), 101-109.

MacKinnon, D. P., Fairchild, A. J., \& Fritz, M. S. (2007). Mediation analysis. Annual Review of Psychology, 58, 593-614.

McKnight, D. H., \& Chervany N. L. (2002). What trust means in ecommerce customer relationships: An interdisciplinary conceptual typology. International Journal of Electronic Commerce, 6(2), 35-60.

Monsuwé, T. P., Dellaert, B. G., \& de Ruyter, K. (2004). What drives consumers to shop online? A literature review. International Journal of Service Industry Management, 15(1), 102-121.

Pérez-Hernández, J., \& Sánchez-Mangas, R. (2011). To have or not to have Internet at home: Implications for online shopping. Information Economics and Policy, 23(3-4), 213-226.

Shah, R., \& Goldstein, S. M. (2006). Use of structural equation modeling in operations management research: Looking back and forward. Journal of Operations Management, 24(2), 148-169.

Sin, L., \& Tse, A. (2002). Profiling Internet shoppers in Hong Kong: Demographic, psychographic, attitudinal and experiential factors. Journal of International Consumer Marketing, 15(1), 7-29.

Smith, H. J., Milberg, S. J., \& Burke, S. J. (1996). Information privacy: Measuring individuals' concerns about organizational practices. MIS Quarterly, 20(2), 167-196. 
Subramanian, N., Gunasekaran, A., Yu, J., Cheng, J., \& Ning, K. (2014). Customer satisfaction and competitiveness in the Chinese eretailing: Structural equation modeling (SEM) approach to identify the role of quality factors. Expert Systems with Applications, $41(1), 69-80$.

Swilley, E., \& Goldsmith, R. E. (2013). Black Friday and Cyber Monday: Understanding consumer intentions on two major shopping days. Journal of Retailing and Consumer Services, 20(1), 43-50.

To, P.-L., Liao, C., \& Lin, T.-H. (2007). Shopping motivations on Internet: A study based on utilitarian and hedonic value. Technovation, 27(12), 774-787.

Verhoef, P. C., Franses, P. H., \& Hoekstra, J. C. (2002). The effect of relational constructs on customer referrals and number of services purchased from a multiservice provider: Does age of relationship matter? Journal of the Academy of Marketing Science, 30(3), 202-216.

Wolfinbarger, M., \& Gilly, M. C. (2001). Shopping online for freedom, control and fun. California Management Review, 43(2), 34-55.

Wu, L.-Y., Chen, K.-Y., Chen, P.-Y., \& Cheng, S.-L. (2014). Perceived value, transaction cost, and repurchase-intention in online shopping: A relational exchange perspective. Journal of Business Research, 67(1), 2768-2776.

Yen, T.-H., da Gama, G., \& Rajamohan, S. (2008). Perceived image of India by US business travelers. Marketing Management Journal, 18(1), 121-131.

Zarei, E., Zainalipour, H., Mohammadi, M., \& Zare, S. (2013). Scale construction and validation for evaluation of training performance in Hormozgan University of Medical Sciences, Iran. Journal of Applied Environmental and Biological Sciences, 3(12), 101-106.

Zhao, X., Lynch, J. G., \& Chen, Q. (2010). Reconsidering Baron and Kenny: Myths and truths about mediation analysis. Journal of Consumer Research, 37(2), 197-206. 